\title{
ゲートの空気吸込みに関する一考察 \\ ON INVESTIGATION OF THE AIR QUANTITY FOR THE GATE
}

\author{
中 島 康 吉* • 巻 幡 敏 秋** \\ By Yasuyoshi Nakajima and Toshiaki Makihata
}

要 旨 放水路トンネルを有するゲートの空気吸込 み現象については従来流れの跳水現象に上る空気吸込み が問題とされ，空気吸込みに関する尖験式が示されてい る。しかしながら該式は筆者らが夷験した模型実験拓上 び入手し得た実物実験などと十分な一致が涩められなか ったので, 本論文ではトンネル内の流水面上に発達する 境界層，あるいは噴流の挔散にもとづく空気吸込みを考 光, 理論的な解析を行なって夷験結果と比較検討したも のである。

\section{1. 粕 論}

放水路トンネルを有するダムではゲートの開閉にとも ない,ゲートからの流出水によってトンネル内の空気が ダム外に運び去られ，トンネル内の気がいちじるしく低 下寸る。このような気压の低下はゲートに刘して空洞現 象や振動など操作上好ましくない原因上なって現われ る。このような危険を防忙し，安全なゲート操作を问能 ならしめるために空気管（Air vent）が設置されてい 子

空気管の設計必要な空気收込量に関する従来の研究

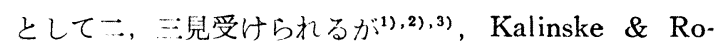
bertson ならびに Campbell \& Guyton らの論文中に 亦されている失験式は空気吸込みの原因を流れの跳水現 象によるるのと考察して空気比 $\beta^{*}\left(\beta^{*}=\frac{Q_{a}{ }^{*}}{Q_{w}{ }^{*}}, Q_{a}{ }^{*}\right.$, $Q_{w}{ }^{*}$ はそれぞれ央験で得られる空気量および流昰であ る）をフルード数をもとに整理されたもので, 実物で得 られた結果とある程度よく一致すると報告された例もあ っで，この车験式が空気管の設計に採用されている現 状にある、ところが空気收込量について筆者らが垁験し た二，三の模型头験打よび惪瀬ダム 1/15 模型5) あるい は近畿地方建設局の好意により入手し得た大野ダムの史 物実験などの結果は上述の车験式とは相当の差があらわ れまったくその一致が浔められなかった。また縮尺模型 夷験から夷物の空気盲を推筀することも考えられるが, 信頼できる換算方法も明確ではなく，空気吸込みの原因 についても不明な点を多分に残しているようである。

そこで本論文では空気吸込み現象を Kalinske \& Robertson らが考察しているように流れの跳水現象と考え

* 工博 日立造船 KK技術研究所

** 正員 日立造船 KK技術研究所
ず,トンネル内の流水面上に発達する境界首, あるいは 噴流の抬散に上るものと考えて以下に検討を加えてみ た。

\section{2. 理論的考察}

筆者らは 表一-1, 表一2 と示すような 2 種類の模型括 よび条件のもとに実験して得られた結果ならびに大野ダ ムの実物実験（尌算に用いた当ダムの寸法を表一3に示 す）で得られた結果からそれぞれの空気比 $\beta^{*}$ を求め Kalinske らと间様な整理方法を試み図示してみると図 一1のようになる。

$$
\text { 図一1 } \beta^{*} \sim F-1 \text { との関係 }
$$

Fig. 1 Relation of $\beta^{*}$ vs $F-1$.

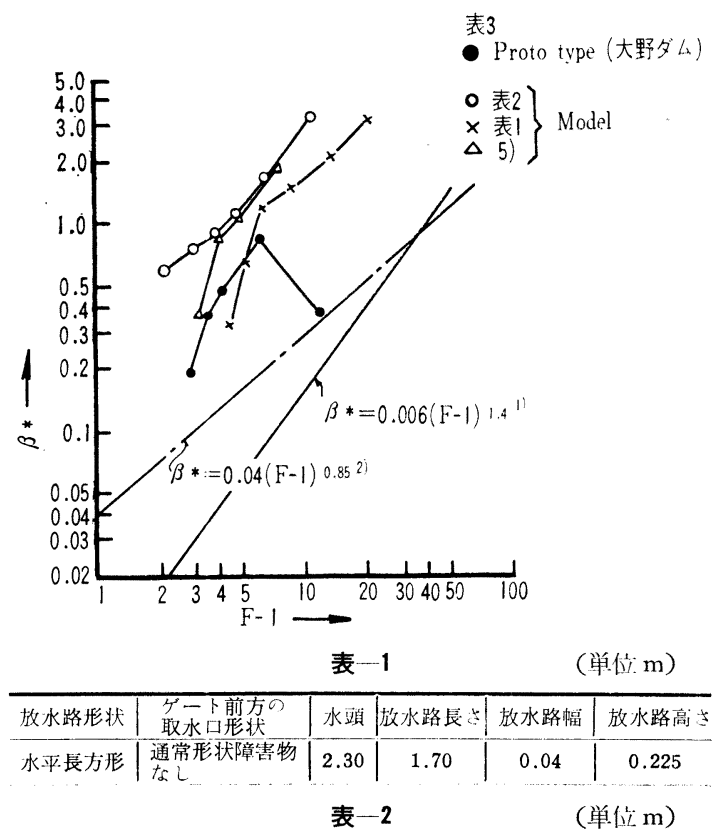

\begin{tabular}{|c|c|c|c|c|c|}
\hline 放水路形状 & $\begin{array}{l}y^{\prime \prime}-卜 \text { 煎方の } \\
\text { 取水口形状 }\end{array}$ & 水頭 & 放水路長さ & 放水路幅 & 放水路高占 \\
\hline 水平長方形 & 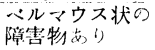 & 2.50 & 0.70 & 0.133 & 0.133 \\
\hline & \multicolumn{3}{|c|}{ 表一3 } & \multicolumn{2}{|c|}{ (単倘 m) } \\
\hline 放水路形状 & 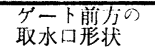 & 水頭 & |放水路長さ & 放水路幅 & 放水路高 \\
\hline 放物線 & 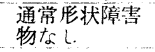 & 34.4 & 34.0 & 3.4 & 5.1 \\
\hline
\end{tabular}

なお，表一1のものは単純化された模型 (Idealized Model) であり, 表一2 のものは関西電力KK黒部川第 4 発電所洪水吐ゲート括よび放水路の1/30 模型である。 
この図から空気比 $\beta^{*}$ は模型で得られた結果も実物で 得られた結果もKalinske の実験式との開きが大きくあ らわれて扣り，この実験式を类物の空気管の設㖕に採用 することには問題があるように思われる。

ここにゲートの空気昅込みを運動量の搪散現象と考 え,つぎのよろな単純化した手段を用いて考察してみる。 その一つは大気の昖散係数に支配されて水平なトンネル 内の流水面上に発達する境界首にもとづ々拡散現象であ るとして境界㐿理論を応用する方法, ほかの一つはゲー トから流出する水流を噴流と考光噴流理論を応用する今 法である。

\section{(1) 大気内の拡散現象}

空気管の入口と空気管出口（ゲート室）とに括ける㞋 力降下がわずかでゲート室の気圧がほぼ大気压等しい と考劣られる場合には放水路トンネル内の空気は非王縮 性流体，すなわら大気と同椂な取り扱いができるので大 気の運動方程式が適用できる。

古典的な大気の運動方程式は $\nu=0\left(\nu=\frac{\mu}{\rho_{a}}\right)$, すなわ ち $\mu=0$ の理想流体についての Euler の運動方程式が 採用されていた。これは空気の粘性として分子力による 粘性が考无られ，大気の運動のような大䙺模の運動には 全然さかないとしていたためである。ところが近年に至 ってろず粘性なる分子粘性、に比較して相垱大きな作用を するものが, G.I. Taylor によって発見されて再び分了. 粘性 $\mu$ の代りにうず粘性係数 $\mu^{\prime}$ を用いた粘性項が大気 の運動方程式に採用されるようになった。うず動粘性係 数（抬散係数ともいわれる） $K\left(K=\frac{\mu^{\prime}}{\rho_{a}}\right)$ を導人するこ とによって大気の運動方程式はつぎのようになる。

$$
\left.\begin{array}{l}
\frac{D u}{D t}=-\frac{1}{\rho_{a}} \frac{\partial p}{\partial x}+K_{x} \frac{\partial^{2} u}{\partial x^{2}}+K_{y} \frac{\partial^{2} u}{\partial y^{2}}+K_{z} \frac{\partial^{2} u}{\partial z^{2}} \\
\frac{D v}{D t}=-\frac{1}{\rho_{a}} \frac{\partial p}{\partial y}+K_{x} \frac{\partial^{2} v}{\partial x^{2}}+K_{y} \frac{\partial^{2} v}{\partial y^{2}}+K_{z} \frac{\partial^{2} v}{\partial z^{2}} \\
\frac{D w}{D t}=-\frac{1}{\rho_{a}} \frac{\partial p}{\partial z}+K_{x} \frac{\partial^{2} w}{\partial x^{2}}+K_{y} \frac{\partial^{2} w}{\partial y^{2}}+K_{z} \frac{\partial^{2} w}{\partial z^{2}}
\end{array}\right\}
$$

また連続の方程式は

$$
\begin{aligned}
\frac{\partial \rho_{a}}{\partial t} & +u \frac{\partial \rho_{a}}{\partial x}+v \frac{\partial \rho_{a}}{\partial y}+w \frac{\partial \rho_{a}}{\partial z} \\
& +\rho_{a}\left(\frac{\partial u}{\partial x}+\frac{\partial v}{\partial y}+\frac{\partial w}{\partial z}\right)=0 .
\end{aligned}
$$

となる。ここで式 (1) に拈いて $K_{x}=K_{y}=K_{z}=\nu$ と するならば周知のように層流状態の Navier-Stokes の 運動方程式となる。な括 $u, v, w$ は $x, y, z$ 軸方向 の分速度， $\rho_{a}$ は空気の密度である。ただし簡単にする ため地球の自転によって流体に働くCoriolis の力は省 略している。

大気の運動方程式をダム放水路トンネル内の空気流の 現象に適用するために 2 次元を考える。流水面からあま
り大きく離れていない距離のところでは空気の乱れは統 訓的に等方性になっていることが G.I. Taylor によっ て見い出されている。この場合の運動方程式は式 (1) の 2 次元の Navier-Stokes の運動方程式, すなわち層 流境界首内に招ける運動方程式と同形になる。したがっ て得られる解は形式的には䦔流境界自の解とまったく一 致する。式 (1) の2 次元流を考光れば境界首の運動方 程式と連続の广j程式は

$$
\begin{aligned}
& \frac{\partial u}{\partial t}+u \frac{\partial u}{\partial x}+v \frac{\partial u}{\partial y}=-\frac{1}{\rho_{a}} \frac{\partial p}{\partial x}+K\left(\frac{\partial^{2} u}{\partial x^{2}}+\frac{\partial^{2} u}{\partial y^{2}}\right) \\
& \frac{\partial v}{\partial t}+u \frac{\partial v}{\partial x}+v \frac{\partial v}{\partial y}=-\frac{1}{\rho_{a}} \frac{\partial p}{\partial y}+K\left(\frac{\partial^{2} v}{\partial x^{2}}+\frac{\partial^{2} v}{\partial y^{2}}\right) \\
& \frac{\partial u}{\partial x}+\frac{\partial v}{\partial y}=0
\end{aligned}
$$

となる。ただしここで $K=K_{x}=K_{y}$ である。

流水面を $x$, それの鉛直方向を $y$ とし, トンネル内の 流水表面を $U(U=\sqrt{2 g H}, H=$ ダム水頭）なる理論流 速で動いている平板と考学ると流水面上の空気は粘性の ために流水面の流速と同一になろろとする現象，すなわ ち搪散現象が起こり水面上の空気は $u^{\prime}$ の速度で運び去 られることになる。またこの現象と同時に流水面は実は 固体の平板でなく相当量の水の飛まつが流水面上の空気 流に搪散されている。この昖散が空気の拡散に支配され ているものとすれば, やはり空気の流速分布と同様に水 の飛まつの濃度分布に境界焦理論の解を適用することが できる。この拡散に括いて S.I. $\mathrm{Pai}^{6}{ }^{6}$ がガス拡散につい て取り扱っていると闰様の方法を用い, 空気による水の 抁散と水による空気找散とが同程度であると考え, 空 気流に拨散されている水の飛まつに相当する空気量が水 流内に搪散され水流とともに運び去られるとすると理論 空気量 $Q_{a}$ は次式によって!古られることになる。

$$
Q_{a}=B\left\{\int_{0}^{\delta}(1-\sigma) u^{\prime} d y+\int_{0}^{\delta} \sigma u^{\prime} d y\right\}
$$

ここで $B$ は放水路の幅, $\delta$ は $x=L$ すなわちトンネルの 出口に招ける境界首の厚さ， $\sigma$ 単位体積中にふくまれ る水の飛まつの濃度で, 単位体積中にふくまれる空気は 1ーのになる。右边の第 1 項は境界图内で運び去られる 空気量であり, 第 2 項は水の飛まつ量であるが, 前述の ようと等量の空気が水流内に拡散されて運び去られると 考えて加えたものである。ところが境界㐿理論から求め

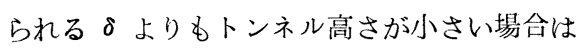

$$
Q_{a}=B\left\{\int_{0}^{\phi}(1-\sigma) u^{\prime} d y+\int_{0}^{\phi} \sigma u^{\prime} d y\right\} \quad(\delta>\phi)
$$

で近似的に空気量が与えられるるのとする。ここで $\phi=$ $s_{0}-s$ で $s_{0}$ はトンネルの高さである。

$U$ なる速度をもつ流れの中に置かれた平板上に発達 する首流境界層内の流速分布 $u$ は一般飞 $u=U f(\eta)=$ 


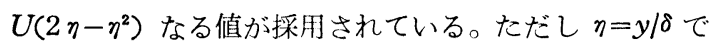
まる。この場合は逆に静止流体中を平板が運動する場合 を考えているから $u^{\prime}=U-u$ となり

$$
u^{\prime}=U\left(1-2 \eta+\eta^{2}\right)
$$

で表わされる。また空気の拡散も水の飛まつの拡散も同 じ式で表わされるべきものであるから

$$
\sigma=1-2 \eta+\eta^{2}
$$

となる。

つぎに理論流量は $Q_{w}=\sqrt{2 g H} \cdot S \cdot B=U \cdot S \cdot B$ とし て示される関係から理論空気比 $\beta$ は次式の上うになる。 式 (5) から

$$
\beta=\frac{Q_{a}}{Q_{w}}=\frac{1}{S U} \int_{0}^{\delta} u^{\prime} d y
$$

式 (9) 飞式 (7) を代入して

$$
\beta=\frac{\delta}{S}\left\{\int_{0}^{1}\left(1-2 \eta+\eta^{2}\right) d \eta\right\}=A \frac{L}{S} R_{K}^{-1 / 2} .
$$

式 (6) 加らは同樣に

$$
\beta=\frac{\delta}{S}\left\{\int_{0}^{\phi / \delta}\left(1-2 \eta+\eta^{2}\right) d \eta\right\}=A^{\prime} \frac{L}{S} R_{K}^{-1 / 2}
$$

となる。ここで $L$ は放水路の長さ， $R_{K}$ はうず動粘性 係数を用いたレイノルズ数 $R_{K}=\frac{U L}{K}, A, A^{\prime}$ は首流境 界層内の流速分布を積分することによって得られる係数 で $A=1.83$ となる。

\section{(2) 噴流の拡散現象}

同種流体中（水対水あるいは空気対空気）に噴出され た際に生ずる噴流の搪散を考党、この搪散にともなうゲ 一トの空気吸込み現象を以下に検討してみる。

ゲートから流出寸る噴流は空気巾へ水が噴出される場 合で泼密には以下の考察は適当であるかどうか問題であ る。その理由として水面を境界としての対称昖散湢, 飛 まつの濃度分布あるいは噴流の流速分仍などの定義はこ の分野での最近の咨験研究によれば適当でないようであ るが，いまだに確立された理論がないように思われるこ とから,ここでは従来の噴流理論がどの程度この現象に 適用できるかを究明しようとしたものである。

まず流出水の境界面を $x$ 軸, それの鉛直方向に $y$ 軸を とり流出水と放水路トンネル内の静止流体 (空気) とが 接触し始める点（ゲート設置箅所）を原点とする。2つ の流体が接触するところには流出水の一様流速 $U(U=$ $\sqrt{2 g H}, H=$ ダム水頭) より 0 亿移り変わる風ができ, 流速の速いものと遅いものとが入り混じる。いわゆる抬 散現象をともなう風ができ，この拡散層の幅は下流に向 い次第に增大寸る。その結果流水境界面にある空気の一 部は流水に誘引されるので, 静止流体の部分には $U$ に くらべて小さいが $y$ 軸方向の流れが生ずる。この流れが 空気吸込みの原因となる。一般飞噴流の運動方程式と連 続の式はつぎのように与えられる。

$$
\begin{aligned}
& u \frac{\partial u}{\partial x}+v \frac{\partial u}{\partial y}=\frac{1}{\rho_{w}} \frac{\partial \tau}{\partial y} \\
& \frac{\partial u}{\partial x}+\frac{\partial v}{\partial y}=0
\end{aligned}
$$

ここに $u, v$ は境界㒸内の $x$ 軸方向の流速打上び $y$ 軸 方向の流速， $\rho_{w}$ は水の密度，ては乱流せん断応力であ る。

式 (12) に捈いて乱流せん断忍小 $\tau は$ Prandtl の混 命距離を用いた式で示せば次式で与㐋られる。

$$
\tau=k \rho_{w} l^{2}\left|\frac{\partial u}{\partial y}\right| \frac{\partial u}{\partial y}
$$

ただし $k$ は定数で Prandtl の運動量輸送理論によれば $k=1$, G.I. Taylor のか（滆）度輸送理論によれば $k=$ $\frac{1}{2}$ となるもので, 一般に噴流理論に招いては後者が採 用されている。 $k l^{2}\left|\frac{\partial u}{\partial y}\right|$ は2.（1）で用いた拡散係数 $K$ と同じ性質のものであるから，これを常数 $K^{\prime}$ とし て取り扱うことも考光られるが，ここでは從来の噴流理 論をそのまま採用する。すなわち噴流理論を適用すれば 式 (14) での混合距離 $l$ は噴流の拡散幅 $b$ 飞比例し, し かも $b$ は流れの境界面に治う距離 $x$ 亿比例寸ることにな り式(14) はつぎのようとなる。

$$
\tau=\frac{1}{2} \rho_{w} c^{2} x^{2}\left|\frac{\partial u}{\partial y}\right| \frac{\partial u}{\partial y}
$$

ここに $c$ は昖散幅を定義する定数である。

式 (12) の運動方程式を解くために $y / x$ に比例する $\xi$ なる変数を導人する。また $u, v$ を求めるために流水

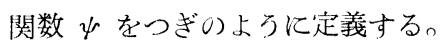

$$
y_{r}=\int u d y=U x \int f(\xi) d \xi=U x F(\xi)
$$

ここにUは流出水の一样流速である。式 (16) から vはそれぞれ

$$
\begin{aligned}
& u=\frac{\partial \psi}{\partial y}=: U F^{\prime}(\xi) \\
& v=-\frac{\partial \psi}{\partial x}=U\left\{\xi F^{\prime}(\xi)-F(\xi)\right\}
\end{aligned}
$$

として算出される。

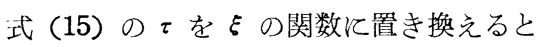

$$
\tau=\frac{1}{2} \rho_{w} c^{2} U^{2} F^{\prime \prime 2}(\xi)
$$

となり, 式 (17) から求められる $\frac{\partial u}{\partial x}, \frac{\partial u}{\partial y}$ 拈よび式 （18）加以誘導される $\frac{\partial \tau}{\partial y}$ を式 (12) 飞代人して噴流 の境界条件を与えることによって $F(\xi),\left\{F^{\prime}(\xi)\right\}$ が求 まる。すなわち

$$
\begin{aligned}
F(\xi)= & c_{1} e^{-\alpha \xi}+c_{2} e^{\alpha \xi / 2} \cos \frac{\sqrt{3}}{2} \alpha \xi \\
& +c_{3} e^{\alpha \xi / 2} \sin \frac{\sqrt{3}}{2} \alpha \xi \ldots \ldots .
\end{aligned}
$$

$$
F^{\prime}(\xi)=-c_{1} \alpha e^{-\alpha \xi}+c_{2} \alpha e^{\alpha \xi / 2} \cos \left(\frac{\sqrt{3}}{2} \alpha \xi+\tan ^{-1} \sqrt{3}\right)
$$




$$
+c_{3} \alpha e^{\alpha \xi / 2} \sin \left(\frac{\sqrt{3}}{2} \alpha \xi+\tan ^{-1} \sqrt{3}\right) .
$$

となる。噴流の境界条件として $u=U, v=0$ となる $\xi=$ $\xi_{1}$ では, $F^{\prime}\left(\xi_{1}\right)=1, F\left(\xi_{1}\right)=\xi_{1}$ 打よび $F^{\prime \prime}\left(\xi_{1}\right)=0, u=$ $0, v=v$ となる $\xi=\xi_{2}$ では $F^{\prime}\left(\xi_{2}\right)=0$ 扔よび $F^{\prime \prime}\left(\xi_{2}\right)$ =0である。

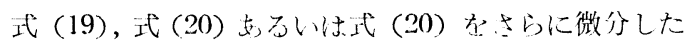
$F^{\prime \prime}(\xi)$ の式に上部の境界条件在代入して数值解析至武又

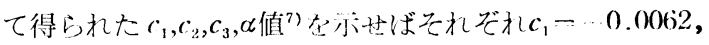
$c_{2}=0.987, c_{3}=0.577, \alpha=11.8$ となっている また式

（15）に示した拡散幅を定義寸る定数 $c$ は史験の結果に よれば $c=0.255$ となっている。

つぎに噴流にともなう水の飛まつの濃度分布である が，ここで水の飛まつの濃度分布は噴流の拡散に支配さ れているものとすれば噴流の流速分布を求めたと同様に 噴流理論の解を適用することができる。すなわち式(20) の関係を拡散幅 $b$ を用いた $\zeta$ の関数 $\left(\zeta=\frac{2 y}{b}=\frac{2 y}{c x}\right.$, $\left.\xi=\frac{c}{2} \zeta\right)$ 飞置き換えると濃度分布 $\sigma$ はつぎのように与 えられる。

$$
\begin{aligned}
\sigma= & F^{\prime}(\zeta)=-\frac{c_{1} \alpha c}{2} e^{-\alpha c / 2 \zeta} \\
& +\frac{c_{2} \alpha c}{2} e^{\alpha c / 4 \zeta} \cos \left(\frac{\sqrt{3}}{4} \alpha c \xi+\tan ^{-1} \sqrt{3}\right) \\
& +\frac{c_{3} \alpha c}{2} e^{\alpha c / 4 \zeta} \sin \left(\frac{\sqrt{3}}{4} \alpha c \zeta+\tan ^{-1} \sqrt{3}\right)
\end{aligned}
$$

単位体積にふくまれる空気は 1 く となるから, 噴流 の昖散に上って運び去られる理論空気量 $Q_{a}$ は次式でな 亲れる。

$$
Q_{a}=B \int_{-b / 2}^{b / 2} u(1-\sigma) d y
$$

式 (22) での積分の上限, 下限は從来の噴流理論によ る水面を境界としての対称拡散幅であり，空気吸込量を 求める場合はちょうど放水路トンネルの須部の壁に喷流 が接触する際の拡散幅を採用すべきであるが，ゲートの 開きによっては積分の上限，下限のうち，特飞下限境界が トンネル底面に達する場合は $-b / 2$ の採用はできなくな り,ゲート開き $s$ とる。このようなゲート開きは対称搪 散と考えれば $s<s_{0} / 2\left(\phi>s_{0} / 2, \phi=s_{0}-s, s_{0}\right.$ はトンネル の高さ， $s$ はゲートの開きである）となる。またこのよ うなゲート開きでは下限境界が底面に達しているため噴 流の一様流速 $U$ 《境界層内の流速となり, 下流に向う にしたがって次第に減少する。そこで簡蚌化のためにト ンネル底面に発達する境界隉を省略し, 噴流の中心を卜 ンネル底面と考えて, R.G. Folsom ${ }^{8}$ が闰種流体中への 軸対称噴流に対して求めた噴流中心部の流速 $U_{c}$ の関係 式 $\left(\frac{x}{S} \geq 8\right.$ または $b=0.255 x, b=2 \phi$ から $7.85 \frac{\phi}{s} \geq 8$ 飞対して $\left.U_{c}-5.13(s / x), U-0.654(s / \phi) U\right)$ を引用して
トンネル底面での流速の境界条件，すなわち $s \geqq s_{0} / 2$ の

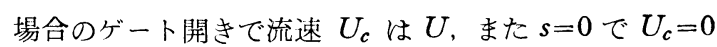
を満足する関係式として簡単に $U_{c}=(s / \phi) U$ と打く。 すると式 (22) の積分の上限, 下限, 噴流の流速分布拓 よび濃度分布はゲート開きが $s<s_{0} / 2$ か $s>s_{0} / 2$ かに上 ってそれぞれつぎの上うに表わされる

$$
s<s_{0} / 2\left(s_{0} / 2-\phi \cdots 1\right) \text { の埸爷は }
$$

$$
Q_{a}-B \int_{-s}^{b / 2} u^{*}\left(1-\sigma^{*}\right) d y \text {. }
$$

ここに $u^{*}=U_{c} F^{\prime}(\xi), \sigma^{*}=\frac{U_{c}}{U} \sigma$ である。

$s>s_{0} / 2\left(0<\phi<s_{0} / 2\right)$ の場合は式 (22) がそのまま適 用できる。式 (22), 式 (23) を とつぎのようになる。式 (23) からは

$$
\begin{aligned}
Q_{a} & =\frac{b}{2} B U_{c} \int_{-2 s / b}^{1} F^{\prime}(\zeta)\left\{1-\frac{U_{c}}{U} F^{\prime}(\zeta)\right\} d \zeta \\
& =S B U \int_{-s / \phi}^{1} F^{\prime}(\zeta)\left\{1-\frac{s}{\phi} F^{\prime}(\zeta)\right\} d \zeta \cdots
\end{aligned}
$$

式 (22) からは,

$$
Q_{a}=\frac{b}{2} B U \int_{-1}^{1} F^{\prime}(\zeta)\left\{1-F^{\prime}(\zeta)\right\} d \zeta=0.25 \phi B U
$$

ここにBは放水路トンネルの幅, $b=2 \phi\left(\phi=s_{0}-s\right)$ であ る。

つぎに理論流量は $Q_{w}-S \cdot B \cdot U$ として表わされるの で，理論空気比 $\beta$ はそれぞれつぎのようになる。式(24) からは

$$
\beta=\frac{Q_{a}}{Q_{u}}=\int_{-s / \phi}^{1} F(\zeta)\left\{1-\frac{s}{\phi} F^{\prime}(\zeta)\right\} d \zeta
$$

式（25）からは

$$
\beta=\frac{Q_{a}}{Q_{w}}=0.25 \frac{\phi}{s}
$$

がそれぞれ得られる。

\section{3. 実験値टの比較}

2.で境界首の理論（噴流理論をもふくむ）、すなわち 運動量の拡散現象から集発して理論空気量, 空気比を定 義してきたのであるが，この考え方が妥当であるかどう か実物夷験および模型央験で得られた結果などをもとに 考察してみる。

\section{(1) 空気量について}

2.（1）の大気内の拡散現象のところで採用した大気 のうず動粘性係数は気流にふくまれるうずの性質に支配 されるものと考えられ, したがって测定された結果も気 象条件はもちろん，物体の大きさや位置に上っても大き く左标されるようである。その一例として佐々枝官が 東海村で行なった小規模の拡散実験9),10)で得られた数值 を示せば， $K_{x}=2.9 \times 10^{-1} \sim 1.5 \times 10 \mathrm{~m}^{2} / \mathrm{s}, \quad K_{y}=5.3 \times$ $10^{-3} \sim 6.7 \times 10^{-2} \mathrm{~m}^{2} / \mathrm{s}$ となっていて, いかにその数值が 
ばらついているかがわかる。しかしながら放水路トンネ ル内に㨟いては気象条件によってほとんど左右されない と考えられるので， $K$ の值はそれはど大きくばらつか ないであろろ。

式（10）を用いて夷験值を整理しそれぞれの実験結果 について $K$ を求めてみると模型では $K=6.44 \sim 9.07 \times$ $10^{-3} \mathrm{~m}^{2} / \mathrm{s}$ ，実物では $K=9.45 \times 10^{-2} \mathrm{~m}^{2} / \mathrm{s}$ が得られる。 Richardson は多くの測定值を整理した結果, 大気のろ ず動粘性係数 $K$ と現象の大きさ $D$ との間に $K=0.2$ $\sim 0.6 D^{4 / 3} \mathrm{~cm}^{2} / \mathrm{s}$ (Dは物体の大きさ $\mathrm{cm}$ で拡散の程度の 大小を示すもので放水路トンネルではトンネル高さと考 えられる）なる関係を見い出している。また Sutton は $K \propto t^{3 / 4}$ なる関係を求めている。ただし $t$ は拡散現象の 行なわれる時間であり， $t$ と物体の大きさとは比例する と考えられるので Richardson の式も Sutton の式も似 通った関係を示するのといえよう。Richardson, Sutton らが導き出している関係と実験結果から得られた $K$ と を比較してみると図一2のようになる。実物および模型 そ扮ける $K$ 值 は Sutton が導 き出している関

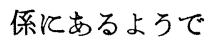
ある。Sutton の 式を $K=\alpha D^{3 / 4}$ と置き換えて実 験結果から 求めてみると図 -2 とも示して あるように $\propto$ 8 が得られる。 ゆえに放水路卜 ンネル内に招け る大気のうず動
図一2 $K \sim D$ との関係

Fig. 2 Relation of $K$ vs $D$.

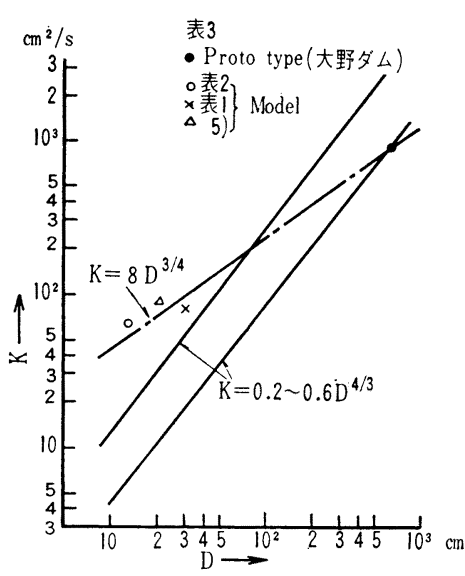

粘性係数 $K$ 怔一応模型, 実物に対して $K=8 D^{3 / 4}$ の 式で推定できる。しかしながら少ない実験結果からの結 論であるので，な括これらの関係については検註を要す るものと考光られる。

式（10）を用いて実験值を整理して得られた $K$ 值を 図-3 $\boldsymbol{Q}_{a} \sim s / s_{0}$ との関係

Fig. 3 Relation of $Q_{a}$ vs $s / s_{0}$.

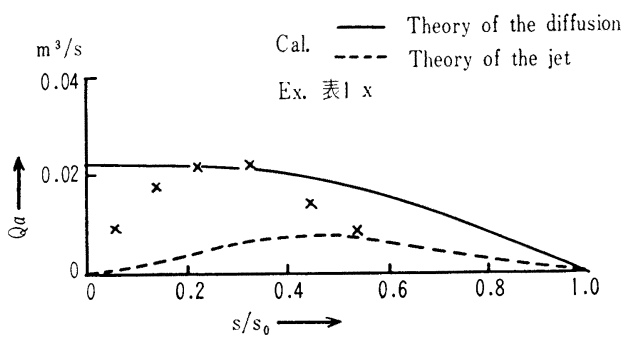

图-4 $\boldsymbol{Q}_{a} \sim \boldsymbol{s} / \boldsymbol{s}_{0} \quad$ との関係

Fig. 4 Relation of $Q_{a}$ vs $s / s_{0}$.

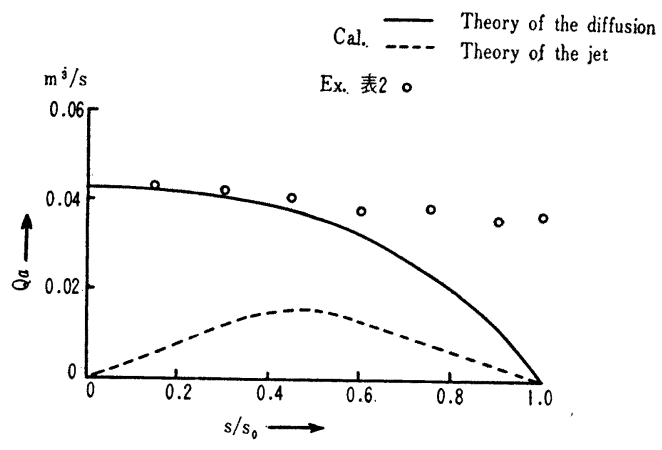

图一5 $\boldsymbol{Q}_{a} \sim s / s_{0}$ との関係

Fig. 5 Relation of $Q_{a}$ vs $s / s_{0}$

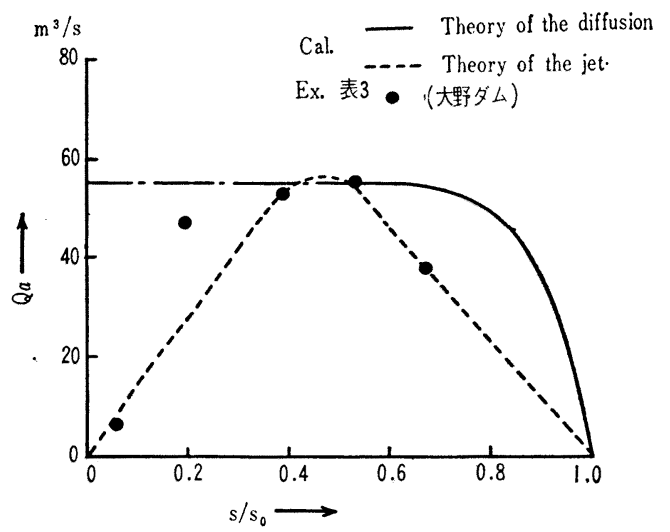

もと飞筆者らが行なった模型実験括よび実物（大野ダ ム)の理論空気量を計算し実験值と比較したのが 図一3, 図一4打よび 図一5 の実線である。

つぎに五十里ダム ${ }^{3)}$ の現地で計測された空気量を示し たのが図一6であるが，五十里ダムに括いてはゲート室 の気圧が大幅に低下したことが報告されて招り，図一6 からもわかるように $s / s_{0}=0.1 \sim 0.8$ の間は空気量はほぼ 一定となっていて, 村技官为指摘しているように圧縮性 流体としての影響が多分に現われていることが認められ る。

そこで圧縮性流体としての取り扱いから空気量を求め

図一6 $\boldsymbol{Q}_{a} \sim \boldsymbol{s} / \boldsymbol{s}_{\mathbf{0}}$ との関係

Fig. 6 Relation of $Q_{a}$ vs $s / s_{0}$

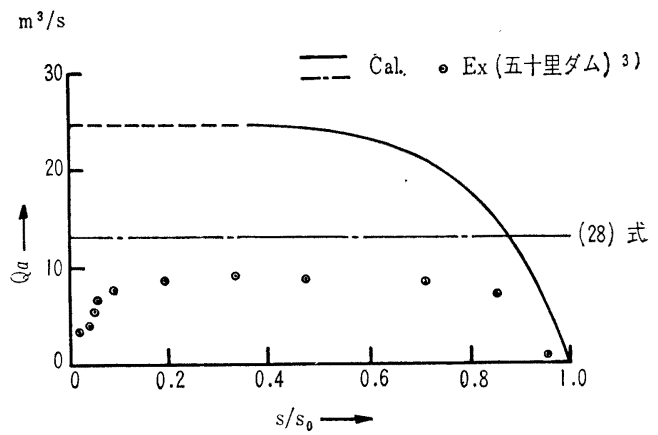


てみる。圧縮性流体の基礎方程式，すなわち断熱変化招 よび Bernoulli の方程式と連続の条件式的ら空気量 $Q_{a}{ }^{0}$ は周知のよう飞次式で与兄られる。

$$
Q_{a}{ }^{0}=f\left(\frac{2}{\kappa-1}\right)^{1 / 2} a_{0}\left\{\left(\frac{p}{p_{0}}\right)^{2 / \kappa}-\left(\frac{p}{p_{0}}\right)^{\kappa+1 / \kappa}\right\}^{1 / 2}
$$

式 (28) 飞招いて最大空気量となる条件は $p / p_{0}=0.527$ である。ここに $f$ は空気管の断面積， $a_{0}=\kappa p_{0} / \rho_{a}$ （音 速), $p_{0}$ は大気压, $\rho_{a}$ は大気圧下飞招ける空気の密度, $\kappa=C_{p} / C_{V}$ (空気では $\kappa=1.40$ である。 $C_{p}=$ 等圧比熱, $C_{V}=$ 等積比熱)，p は任意の点の気圧であるが，ここで はゲート室内の気圧となる。

図一6に执いて鎖線で示した值は式 (28) 飞 $p / p_{0}=$ 0.527 を代入して求められる最大空気量である。放水路 トンネル内の大気のろず動粘性係数は図一2 亿も示して あるように $K=8 D^{3 / 4}$ で求められるので, 五十里ダム の $K$ 值を算出してみると $K=4.3 \times 10^{-2} \mathrm{~m}^{2} / \mathrm{s}$ が得ら れ，この值をるとに理論空気量を計算して示したのが実 線である。

以上の理論式は境界并理論を用いて空気の拡散と水の 拡散とを考虑して導いたものであるが，ゲート開度の小 さなときは，水流のほとんど全部が飛まつ状となって拡 潵されているため理論式を導く際江採用した種々の仮定 を満足しなくなるので，計算值と実験值は一致しないの

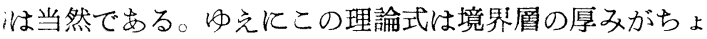
万どトンネル頂部に接触するような状態怙よびそれ以上 のゲート開度の場合飞適用されるべきものである。

つぎにゲートから流出する水流を噴流と考察して噴流 の拡散とこれとともなう水の飛まつの䀼度分布とを考虑 して誘導した式 (24)，(25) を用いて筆者らが行なった 模型実験括よび実物（大野ダム）についての理論空気量 を算出し実験值との比較を武夕たのが 图一3，図一4 括 よび図一5 の点線である。計算值と実駼值との数值的な 一致の覀い一つの原因として考兄られるのは, 噴流理 論は空気中に空気を噴出せしめたときの実験值から定数 を定めているため，ここで考光ているょうな空気中に水 が噴出される場合にそのまま適用できないためであり， また寸法効果についてもなんら考慮されていないための ものと考光られる。しかしゲート開度の小さい場合には 定性的には境界首理論を適用するよりもすぐれているよ ろに考えられる。ゲート開度の大きい場合には境界圈理 論を適用して考察するほうが実験值とのよい一致が認め られる。な招図一4の実験值はゲート開度が增大するに したがって差が現われているのは表一2にも示してある よろにゲート前方にベルマウス状の障害物があり，この ため流出水は遠心流のような流れとなってゲート下部で の流れの縮流が大きく, $s / s_{0}=1.0$ 飞扔いてもトンネル 頂部と流水面とにかなりのすきまを生じて沏り，空気吸
込みの現象をともなっていたことによる。

\section{(2) 空気比について}

大気内の拡散現象から求められる理論空気此，噴流の 搪散現象から求められる理論空気比をそれぞれ式 (10), (11)，(26)，(27）から算出し実験值の空気比之比較し たのが図一7である。実線と鎖線は式 (10)，(11）によ

$$
\text { 图-7 } \beta-8 / s_{0} \text { との関係 }
$$

Fig. 7 Relation of $\beta$ vs $s / s_{0}$
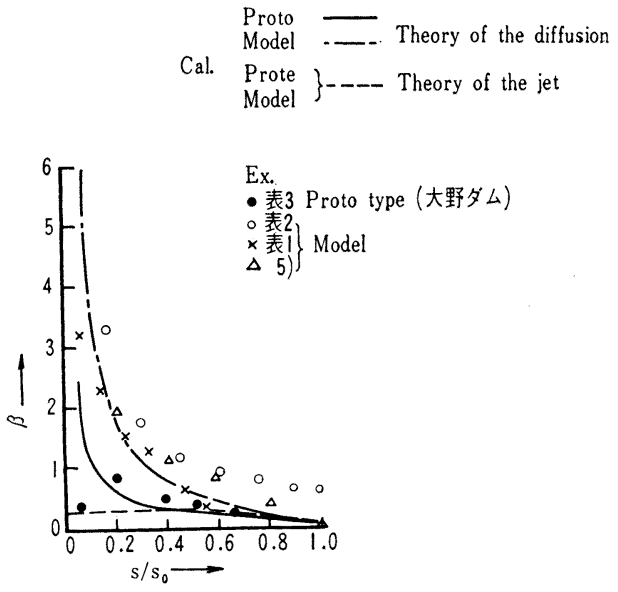

ったものでそれぞれ実物，模型についてのものである。 点線は式 (26)，(27）によったものである。

$\beta$ と $\beta^{*}$ との関係计式 (9)，(26)，(27) などから明 らかなように， $\beta^{*}=\beta / c_{c}$ と表わされる。流量係数 $c_{q}=$ $c_{c} c_{v}$ となるので, $c_{v} \doteqdot 1.0$ と扮くと $c_{c} \fallingdotseq c_{q}$ となる。図 中での計算値と実験值との相違は $1 / c_{\boldsymbol{q}}$ の差飞等しくな る。ゆえに流量係数 $c_{\boldsymbol{q}}$ の小さくなるよろな流れを生ず るゲートに招いてはその差が大きく現われている。

四からわかるようと計算値と実験值との間にはな招を の差が認められるが順向としてはよく一致しているの で，理論式の近似度を考察すれば本論文で試及た考察は 罗当であるといえる。

\section{4. 結 論}

ゲートの空気吸込みを運動量の拡散現象と考兄，大気 内の拡散現象方るいは噴流つ拡散現象として解析し，そ の妥当性について考察を加えた。その結果ゲート開度の 小さい場合の空気吸込みについては噴流理論のほうが定 性的によく一致するが，ゲート開度の大きいときは大気 のうず動粘性係数を導入して誘導した境界屏理論を適用 したほうが罗当である。

大気のうず動粘性係数を適確汇推定することができれ ば，2（1）で考察した理論によって空気财込量を実用 的には十分の精度で計算できるものと考学られ，したが ってまず大気のうず動粘性係数の值をさらに明確行する ための実験が数多く行なわれることが望まれる。しかし ながらこの現象を根本的に解明して行くためには流速分 